\title{
Symbolic Violence in Early Childhood Education
}

\author{
Lia Aprilianti ${ }^{1, *}$, Hani Yulindrasari ${ }^{2}$ \\ ${ }^{1,2}$ Department of Early Childhood Education of Postgraduate Studies. University of Education \\ *Corresponding author. Email: lia@upi.edu
}

\begin{abstract}
This paper aims to analyse the practices of symbolic violence in ECE. Symbolic violence is an invisible violence that cannot be seen clearly without a critical and in-depth understanding of the person who experienced it (the victim). Symbolic violence often undetectable since it is recognized as something natural and must occurs. Symbolic violence comes about through internalized collective values, which have been assumed as the truth, proper, reasonable and are justified as a culture. Using Bourdieu's theory of symbolic violence, this paper analyses the internalized collective values that led to symbolic violence in early childhood education settings.
\end{abstract}

Keywords: Early childhood education, symbolic violence, habitus, capital, field.

\section{INTRODUCTION}

The purpose of this paper is to describe symbolic violence in early childhood education. Early childhood education has become a strategic institution to provide good stimulation in the development and growth of early childhood in preschool institutions. Referring to the objectives of national education [1], early childhood education is presented as an effort to prepare young children's readiness for basic education and their future as well as to be Indonesian good citizens [2]. So that it is hoped that students will become human beings who believe and fear God Almighty, have noble character, are healthy, knowledgeable, capable, creative, independent, and become democratic and responsible citizens [1].

Based on these objectives, currently the orientation of early childhood education institutions, which are mostly managed by the private sector, has undergone a significant change in orientation [3]. Based on the results of the literature review obtained, the shift in orientation is a shift in the interests of early childhood education providers which tends to meet structured materialist needs, resulting in policies and learning processes that are no longer in favour of the interests of students [4], [5].

The changes in orientation are translated in various policies of ECE institutions to be the rules. Parents of students and students must follow these rules if they want to be recognized as part of the students of the institutions. This is what gives birth to violence that is not visible physically, and is not even recognized by the victim, in this case parents and students [6]. This is done forcibly but subtly, so that it does not appear physically and is carried out systematically by those who have power and dominate [7], so that it becomes a culture and values that are considered normal and accepted as something that should happen. This process in Bourdieu terms is achieved through sustainable planting [8].

This action has had an impact in the form of violence in early childhood. However, because the violence committed was not physically visible, it was not even felt by the victim as a form of violence. In fact, this form of violence is a form of violence that can have major negative implications for life. This violence is called symbolic violence [9].

Before explaining more clearly about symbolic violence, I will briefly review the violence that generally occurs in school environments, namely physical and non-physical violence, both of which will have an impact on the quality of education received by students [10].

As I have previously mentioned, one type of violence experienced by students is symbolic violence. Symbolic violence is formed because of differences in the structure of the habitus [11], [10]. Symbolic violence is a mechanism of violence carried out by the dominant class slowly but surely, so that the dominated class does not realize that it is the object of violence [12].

This symbolic violence specifically refers to the lower middle class of students or as the subject of receiving symbolic violence [13]. This is because, schools as an arena (field) unconsciously provide space for students who come from the middle to upper class (middle up) to dominate through policies that are subtly 
intended only for students with economic, social, and economic stability and culture [14], [15].

Writing this paper intends to describe forms of symbolic violence in early childhood education [4]. Besides that, I write research on this topic because it is still rarely found. The goal to be achieved is for school institutions and teachers to be more critical of forms of symbolic violence, so as to reduce the impact experienced by students.

\section{THEORETICAL FRAMEWORK}

This paper uses Bourdieu's lens in analysing practices of symbolic violence. More specifically in this paper, the author raises the symbolic violence that occurs in early childhood education [4]. Before explaining further about symbolic violence, it will be more comprehensive if we first understand the basic concepts of Bourdieu's theory.

Actually, the basic concepts of Bourdieu's theory are coloured by many philosophical thoughts [16]. The following is Bourdieu's concept of theory which will be useful for explaining the meaning of symbolic violence and then associated with educational institutions and schools in this case early childhood education:

Habitus is defined as social values that are lived by humans, and are created through a process of socialization of values that lasts a long time, so that it settles into a way of thinking and behaviour patterns that settle in the human being. Habitus is also a lifestyle, values, dispositions, and expectations of certain social groups to form a collective rhythm that all members must obey [4]. Objectivism emphasizes the role of structure in determining actors and the social environment. Meanwhile, subjectivism thinking looks at the micro side which emphasizes the actor's actions [17]. Bourdieu combines the two thoughts, because according to him, not everything is influenced absolutely by the structure and actors but there is a reciprocal influence between the two, so that the relationship is dialectical $[18,19]$.

Capital is divided into three things [20], namely social capital, cultural capital, and symbolic capital. Social capital refers to a group of people who are actually connected to the ownership of a network of relationships, knowing and acknowledging each other. The form of social capital is like friendship, or an institutionalized form such as family, ethnicity, school, etc. [9]. Cultural capital refers to a series of individual abilities and expertise, such as attitudes, ways of speaking, appearance, ways of getting along, and so on [8]. Bourdieu [6] classifies cultural capital into three dimensions, namely Capital culture incorporate (embodied) which includes general knowledge, skills, inherited talents, cultural values, religion, norms, and others. Capital culture objective (objectified) which includes ownership of high value cultural objects and Capital culture institutionalise (institutionalized) which includes degrees, educational levels, certain skills acquired through education levels. Symbolic capital according to [11] is a form of capital that comes from another type, which is recognized and regulated as something legal and natural. This symbolic capital is in the form of choosing a place to live, choosing a school, and others.

Field is a place where the actors actualize the habitus, but also as a place where habitus is produced [4]. There are various fields, such as the education, the business, the artist, and the political. If we want to succeed in a field, we must have the right habitus and capital [15].

Class; In a journal written by [20] there are three classes in Bourdieu's view. First, the dominant class (bourgeoisie), which is characterized by sizable capital ownership. The dominant class is also able to impose its identity on other classes. Second, the petty bourgeoisie, they are positioned into this class because they have the same character as the bourgeoisie, namely they have the desire to climb the social ladder. Third, the popular class. This class is a class that has almost no capital, be it economic capital, cultural capital or symbolic capital. They are in a position that tends to accept the domination of the dominant class, and tends to accept whatever the dominant class forces.

Violence and Power; Bourdieu said that violence is in the circle of power, its meaning is that violence is the base of a power practice. This power is mostly exercised by the dominant class to dominate, resulting in acts of violence [18], [19], [20].

\section{DISCUSSION}

\subsection{Early Childhood Education and The Symbolic Violence Practices}

Related from the concept of education that can be given to children from an early year with a theoretical perspective that is used as a reference in this paper, the education institutions are a form of Field and Capital [4] which has been widely accepted by the community as a strategic place in helping children optimize their children's growth and development.

In this case, school is also a form of power [5]. This means that the education provider initiates a number of rules that need to be followed by all students. Sometimes the rules are made to see all children with the same perspective, so whether they realize it or not this results in gaps between students. In addition, regulations made often marginalize some of their students so that violence has occurred unconsciously [20]. This type of violence is not felt physically, because it is gentle and continuous so that it is legitimized as 
something that should happen. This violence is what is called symbolic violence [9].

Symbolic violence appears as a form of habitus, capital and arenas that are owned and encountered by children. The three of them are a series that cannot be separated and bind each other [10]. I will further describe the forms of violence that commonly occur in early childhood education institutions, including the following:

\section{Wear uniform clothes and accessories.}

This is the rule most commonly found in early childhood education. Educational institutions require the child's parents to pay a predetermined fee, to pay for the facilities that will be provided to the child during the educational process. This is significantly related to social class among high-income and low-income parents [13]. For parents with high incomes, of course there is no problem when spending some funds to pay for these costs. However, this becomes problematic when faced by parents who do not have financial adequacy to meet the uniform purchasing rules. automatically, this becomes a burden for low-income parents. In other words, just meeting primary needs is difficult enough, then the cost of purchasing uniforms must be added. Conditions like this also have implications for the existence of labelled and ordinary early childhood education institutions, as if this builds a wall of exclusivism between early childhood education institutions and one another [10].

\section{Awarding.}

Although giving awards is part of a basic need, the appreciation made by the teacher is an effort to increase children's enthusiasm in completing assignments and to do good on that day. This is a condition for obtaining awards by children. If it does not meet what the teacher expects, then the award is not given. Common examples of awards that teachers give are stars or smiley stickers [10].

\section{Message transmission}

This relates to various languages and terms conveyed by educators through various language symbols. In practice, the process of delivering messages that teachers do in schools only uses Indonesian as the general language of instruction. Even though not all children have the same first language background. In different conditions, actually not a few children better understand the concept of learning in the local language or the language of the area where they live [19]. Without realizing it, this form of violence is a habitual imposition that is mostly used by children with high social class backgrounds.

\section{Field study (field trip)}

This program is an activity that is routinely carried out periodically, usually children will be asked a fee to participate in it. Without realizing it, this shows a subtle meaning of the power of educational institutions with habits that are mostly carried out by children who come from middle- and upper-class families [13].

\section{Providing the same daily activities.}

Implementation of the learning activity process, the teacher makes daily activities that will be carried out by all children in their class uniformly. Even though maybe not all children want to do these activities. This is also a form of power relations that occur between teachers and students, teachers exercise their dominance in determining learning activities which according to them are good without paying attention to the different needs of each child [4].

\subsection{How to Reduce Symbolic Violence in Early Childhood Education?}

Based on the description that has been mentioned above regarding the forms of symbolic violence that occur in children's education early age. I really hope this can be understood well, so that the perceptions of institutions, teachers and related parties towards learning and policies issued are more equitable for their students to reduce practices of symbolic violence that occur in the school environment.

In this regard, as observers of the world of early childhood education. The following are efforts that can be made to reduce the practice of symbolic violence in early childhood education [20]. Are as follows:

a) Educators should be more sensitive to the students' social, cultural, economic backgrounds and values in their home environment. So that it is wiser in making lesson plans and can apply them more fairly.

b) Educators are expected to be established an understanding of a contextual curriculum implementation. For example, using the language of instruction in the local language that is usually used by children in the surrounding community

c) Early childhood education institutions need to review the application of rules that indicate acts of symbolic violence and should apply egalitarian principles, in the context of building a just education.

d) Educators understand the diversity of students' potentials to be able to build positive values in children without any discrimination.

e) Early childhood education institutions should review programs based on the needs and unique characteristics of the students. 
f) Early childhood education institutions should understand children as playful and creative in exploring various things they want to know and understand, so that education is developed not only based on institutional interests but also based on the children's voices.

\section{CONCLUSION}

Early childhood education has provided a constructive role in civilized human life. Therefore, education should be able to develop humans as subjects of life in order to understand their roles and functions in life. Early childhood education is believed to have a strategic role as early education in building this understanding. Early childhood education needs to be interpreted as a whole, as education to construct children according to their essence [2]. This understanding is an effort to minimize errors in educational praxis that deviate from the nature of child development.

These mistakes are reflected in the existence of various violent practices, one of which is symbolic violence. Symbolic violence is violence that is very dangerous and has a significant impact on the child's future life [12]. Therefore, educational practice needs to be developed with a substantial understanding of education which is not only understood as something that is only practical-methodological.

But deeper than that, it needs to be understood as an effort to form a complete human being, based on the principle of social justice. This fundamental understanding must underlie the implementation of education, especially early childhood education. Figures and tables should be placed either at the top or bottom of the page and close to the text referring to them if possible.

\section{REFERENCES}

[1] Ministry of Education and Culture of the Republic of Indonesia. Sistem pendidikan Indonesia. UU No.20 Tahun 2003[Internet]. 2003.6-8p. Available from: http://simkeu.kemdikbud.go.id/index.php/ peraturan 1/8-uu-undang-undang/12-uu-no-20tahun-2003-tentang-sistem-pendidikan-nasional

[2] Rohani C. Early childhood education. Journal of College Teaching \& Learning (TLC). 2010;7(1):13-6.

[3] Saepudin A. Problematika Pendidikan anak usia dini di Indonesia. Cakrawala Dini. Jurnal Pendidik Anak Usia Dini [Internet]. 2010;4(1). Available from: http://ejournal.upi.edu/index.php/cakrawala dini/article/view/10371/6425.
[4] Nash R. Bourdieu on education and social and cultural reproduction. British Journal of Sociology of Education. 1990;11(4):431-47.

[5] Bourdieu P. The state nobility: Elite schools in the field of power. Oxford: Stanford University Press; 1998.

[6] Chamboredon JC, Prevot J. Changes in the social definition of early childhood and the new forms of symbolic violence. Theory and Society. 1975;2(1):331-50.

[7] Bourdieu P. Symbolic power. Critique of Anthropology. 1979;4(13-14):77-85.

[8] Harker R. Bourdieu-education and reproduction. In Harker R, Mahar C, Wilkes C, editors. An Introduction to the Work of Pierre Bourdieu. London: Palgrave Macmillan; 1990. pp.86-108.

[9] Flam H, Beauzamy B. 11 Symbolic violence. In Delanty Y, Wodak R, Jones P, editors. Identity, Belonging and Migration. Cambridge: Liverpool University Press; 2008. pp.221-328.

[10] Fachruddin F. Book Review: Kekerasan Simbolik di Sekolah. Sukma: Jurnal Pendidikan 2018;2(2):311-327.

[11] Harrits GS. Political power as symbolic capital and symbolic violence. Journal of Political Power. 2011;4(2):237-58.

[12] Umanailo M, Basrun C. Mengurai kekerasan simbolik di sekolah: Sebuah pemikiran Pierre Bourdieu tentang habitus dalam pendidikan Maluku: University of Iqraburu; 2018.

[13] Weininger EB. Pierre Bourdieu on social class and symbolic violence. In: Wright EO, editor Alternative Foundations of Class Analysis [Internet]. 2002.116-66p. Available from: https://www.ssc.wisc.edu/ wright/Found-all.pdf.

[14] Adib M. Agen dan struktur dalam pandangan Piere Bourdieu. Jurnal BioKultur [Internet] 2012;1(2):91-110. Available from: http://journal.unair.ac.id/download-fullpapers-01 Artikel Agen dan Struktur dalam Pandangan Pierre Bourdieu. Revisi 20 Okt 2012.pdf

[15] Bourdieu P. Social scape and symbolic power. Sociological Theory. 1989;7(1):14-25.

[16] Bourdieu P, Passeron JC, Nice R. Education, society and culture. Trans. Richard Nice. London: SAGE Publisher; 1977.

[17] Dicks H. Pierre Bourdieu: Key concepts. French Studies: A Quarterly Review. 2010;64(4):517-8

[18] Galtung J. Cultural violence. Journal of Peace Research. 1990;27(3):291-305. 
[19] Bourdieu P, Wacquant L. An invitation to reflexive sociology. London: University of Chicago Press; 1992.

[20] Goldstein RA. Symbolic and institutional violence and critical educational spaces: In the name of education. Journal of Peace Education. 2005;2(1):19-38. 